\title{
Predictors of Retention and Passing the National Council Licensure Examination for Registered Nurses
}

\author{
Nancy Elkins \\ College of Health Professions, School of Nursing, Marshall University, Huntington, WV, USA \\ Email: elkinsn@marshall.edu
}

Received 5 March 2015; accepted 20 March 2015; published 24 March 2015

Copyright (C) 2015 by author and Scientific Research Publishing Inc.

This work is licensed under the Creative Commons Attribution International License (CC BY). http://creativecommons.org/licenses/by/4.0/

(c) (i) Open Access

\begin{abstract}
Using Seidman's retention formula as a theoretical foundation, this study investigated historical data from a Bachelor of Science (BSN) nursing program to determine whether the admission variables of the preprogram grade point averages (GPA), American College Testing (ACT) scores, anatomy and physiology course grades, and/or the Health Education System Inc. (HESI) Exit Exam scores could predict completing the nursing program, as well as passing the NCLEX-RN. A significant relationship $(p<0.01)$ was identified between the preprogram GPA, ACT scores, anatomy grades, and the HESI Exit Exam scores with the completion of the BSN program and passing the NCLEX-RN.
\end{abstract}

\section{Keywords}

Attrition, HESI Exit Exam, NCLEX-RN Exam, Nursing Student, Retention, Seidman's Retention Theory

\section{Introduction}

The nursing shortage currently affecting the United States has challenged colleges of nursing to educate nurses at a faster pace to meet the rising demand for health care according to the American Association of Colleges of Nursing (AACN) [1]. Completing the nursing program and passing the National Council Licensure Examination for Registered Nurses (NCLEX-RN) upon graduation is important for students, faculty, and nursing programs due to the critical nursing shortage [1] [2]. The registered nurse (RN) workforce is one of the top ten occupations in the United States with an expected job growth of $26 \%$, which is an increase of 1.2 million nursing jobs through 2020 [3] [4]. Because this nursing shortage continues to grow, nurse educators cannot afford to lose 
qualified students hoping to become RNs and must increase the retention rate of nursing students who take one of the limited, sought-after positions in a nursing program [5]-[7]. Graduation rates for BSN programs are less than 50\% nationwide, even though the National League for Nursing Accrediting Commission (NLNAC) recommends that an acceptable retention rate is $80 \%$ [8]-[10].

This correlational study used Seidman's retention theory [11] as a guide for assessing the academic variables and investigated the relationship between the independent variables: preprogram GPA, ACT assessment scores, course grades in anatomy and physiology, and/or the HESI Exit Exam scores. Most studies pertaining to predictors related to retention of nursing students were not found to indicate the use of any theoretical frameworks as a basis for conducting their studies. Little empirical data exist regarding retention in a Bachelor of Science (BSN) nursing program and the ability to predict success on the NCLEX-RN exam using student scholastic and aptitude data. In this study, the factors were explored that may influence the retention rate of nursing students and the nursing educator's need to determine the possible predictors of completing the BSN nursing program at a 4-year college in the eastern part of the United States and passing the NCLEX-RN licensure exam.

\section{The Problem}

The current nursing shortage has created a demand for RNs in the workforce that is expected to continue to grow. According to the Government Affairs Committee of the American Nurses Association [12], it is predicted that by 2022 that the United States will need more than one million additional nurses to fill both new nursing jobs and replace the wave of retiring nurses. As the baby boomer generation, which is the largest generation of the United States and includes individuals born between 1946 and 1964, reaches the age where they need nurses to care for them, they will be challenged to find qualified and competent nurses to help with their health care needs, according to the American Association of Retired Persons (AARP) [13]. Thus, as the population ages, the growing need for RNs is expected to intensify the nursing shortage [3] [12].

The public's need for nurses is projected by the Bureau of Labor Statistics [4] to grow faster than for any other profession. The average age of an RN is 46.8 years, with only $8 \%$ under age 30 , which helps contribute to the shortage of nurses [3] [12]. As these RNs get ready to retire within the next 15 years, there will not be enough new graduate nurses to fill these positions, which will only make the nursing shortage more critical in years to come. Even with a 5.7\% increase in baccalaureate nursing programs in 2010, this small increase will not be sufficient to meet the future projected nursing shortage [3]. In a recent report, nursing schools in the United States were unable to accept 67,563 qualified applicants in 2010 from baccalaureate and graduate nursing programs due to lack of sufficient number of faculty, classrooms, and clinical sites, as well as budgetary issues [3].

Due to the nursing shortage, most nursing programs face pressure to increase their enrollment and expedite the entry of these new graduate nurses into the workforce. Nursing programs also face the pressure of having the graduates pass the NCLEX-RN licensure exam on the first attempt because not maintaining at least an $80 \%$ passing rate can be a factor jeopardizing nursing program accreditation status [14] [15]. The NCLEX-RN licensure exam is the standard for all undergraduate nursing schools to determine if the graduate nurse is prepared to provide safe and competent care, but the pass rate for the exam is also a way to judge the effectiveness of the nursing program [16]. Nursing programs are also limited to the number of students who can be admitted; therefore, it is important that those students admitted complete the program in order to increase the overall number of nursing graduates [17].

Researchers have identified the shortage of trained nursing faculty as a primary factor in the nursing shortage [3] [18]. There is a shortage of nurses with master's or doctoral degrees, which is a qualification required to teach nursing students in the RN programs [15] [19]. In a survey of nursing faculty in Colorado, the results indicated that the reasons for faculty shortage included the retirement of faculty, teaching workload, compensation, cost of graduate education, and the lack of sources of funding or scholarships for graduate education [20].

Many nursing programs are using external independent testing to help predict if the student will pass the board exam on the first attempt [20]. The Health Education System Inc. (HESI) exam, a problem-based learning (PBL) exam often used to measure preparedness for taking the NCLEX-RN exam and for remediation. The HESI Exit Exam is given to the nursing students prior to graduating, and the scores are used to predict success on the first time passing of the NCLEX-RN examination. This exit exam is made to simulate the NCLEX-RN blueprint, and retesting can be used to evaluate the effects of remediation often required if the student does not meet the school's benchmark score for passing the exam [21]. The most common benchmark score used is 850, 
which has been reported to be $97.5 \%$ accurate in predicting success, and a score of 900 or above has been reported to be $98.3 \%$ predicting of success [22].

\section{The Purpose}

The purpose of this quantitative retrospective study was to investigate the possible predictors of success in completing the baccalaureate nursing program at a college in the eastern part of the United States and passing the NCLEX-RN licensure exam. Using Seidman's theory [11] as a guide for assessing the academic variables, this correlational study investigated the relationship between the independent variables: preprogram GPA, ACT assessment scores, course grades in anatomy and physiology, and/or the HESI Exit Exam scores.

Seidman's formula [11] for student retention shows that successfully completing a program of study and graduating is a goal that is attainable for these at-risk students if they are identified early on and early intervention or assistance is made available. The majority of the literature that pertained to variables in achieving success in nursing programs or on the NCLEX-RN did not indicate the use of any theoretical frameworks as a basis for conducting their studies. Using Seidman's retention formula as the theoretical framework, identifying the variables that best predict student success in completing the baccalaureate nursing program and passing the NCLEX-RN may help nurse educators to recognize these at-risk students and thus will help increase the retention rates of the nursing students.

The research questions addressed in this study are:

1) Is there a significant relationship among selected factors (preprogram GPA, ACT scores, anatomy and physiology course grades, HESI Exit Exam scores) related to completion of the BSN nursing program and passing the NCLEX-RN licensure exam?

2) Does the HESI Exit Exam score predict success on the NCLEX-RN licensure exam?

The following secondary questions addressed in this study are:

3) What preprogram admission criteria best predicted completion of the BSN nursing program and passing the NCLEX-RN licensure exam?

4) What is the HESI Exit Exam score range that best predicted the first time pass rate on the NCLEX-RN licensure exam?

\section{Theoretical Framework}

The theoretical framework used for this study is based upon Seidman's retention formula for student success [11]. According to Seidman's retention formula for student success, retention refers to a student meeting their goal of graduating from a major area of study or discipline. Through early identification of students who are likely to be unsuccessful, assistance in helping these at-risk students can begin as soon as they are identified as likely to be unsuccessful. Seidman argued that early intervention that is intensive and continuous will help with student retention and help the students be successful by meeting their goal of graduating.

\section{Sample}

The sample for this study includes a convenience sample of BSN nursing students from the two graduating classes of May 2010 and May 2011, which were admitted in the fall semester of 2007 and 2008. The sample for this study included all the students admitted to the BSN program in 2007 and 2008, which was a total of 201 students. However, 14 of those students were missing data from their student files, so a total of 187 of the 201 met the criteria for inclusion in the study. The sample was mostly female, Caucasian, and composed of traditional college age students of 23 years or younger. The setting for this study was a baccalaureate nursing (BSN) program at a large, state-supported public university in the eastern part of the United States.

\section{Data Collection}

The data were collected for this study from student records maintained by the BSN program, based on archival data, which are "data taken from records collected by educators or educational institutions" [23]. One hundred eighty-seven $(N=187)$ of the 201 enrolled students met the criteria for inclusion in this study. The categories of the data collected included the preprogram GPAs, ACT scores, course grades in anatomy and physiology, the HESI Exit Exam scores, graduation status in the BSN program, and NCLEX-RN exam status. The gradua- 
tion status of the students was coded as 1 for completing the program, and coded 2 for those who did not complete the program. The NCLEX-RN exam status was coded 1 for passed and 2 for failed the exam. The minimum accepted course grade in the BSN program is a $\mathrm{C}$, so the data analysis included only grades of $\mathrm{C}$ or higher. The grades of $\mathrm{C}$ were coded as a 2 , grades of $\mathrm{B}$ as a 3 , and the grades of $\mathrm{A}$ were coded as a 4 .

\section{Results}

The results revealed that of the 187 of the students that met the criteria for the study, 136 students (72.7\%) completed the BSN program and 51 students (27.3\%) did not complete the BSN program. The Pearson R correlational statistical test and descriptive analysis procedures were used for the data analysis. The descriptive analysis of the population in the study revealed that $84.5 \%$ were female; $15.5 \%$ were males; $96.3 \%$ were Caucasian; and the minorities were $1.6 \%$ or less. The findings support research that nursing is still a predominantly female profession with an underrepresentation of minorities in nursing [24] [25]. The sample of the minority nursing students in the study was not sufficient to demonstrate a significant difference in retention based on race.

\subsection{Research Question 1}

The results revealed that there is a significant relationship between the preprogram GPA, ACT scores, anatomy course grades and completing the BSN program and passing the NCLEX-RN exam. The results revealed the correlation is significant, $p<0.05$, in the relationship between the preprogram GPA and completing the BSN program and passing the NCLEX-RN exam. The results showed 20\% (2 out of 10) failed the NCLEX-RN with a preprogram GPA of <3.0. In the range of GPA 3.0 - 3.99, there were 10\% (12 out of 116) of the students failed the NCLEX-RN exam on the first attempt. Of the 10 students with a GPA of 4.0, 10\% (1 out of 10) of the students failed the NCLEX-RN exam on the first attempt. The results also showed that there were twice as many students who failed the NCLEX with a GPA of 2.99 or less compared to a preprogram GPA of 3.0 to 4.0. The findings on the significant correlation between the preprogram GPA and passing the NCLEX-RN exam upon graduation support existing research findings that GPA is predictive of nursing program completion and passing the NCLEX-RN [5] [26]-[30].

This study found that the correlation is significant, $p<0.05$, between the ACT scores and if the student passed or failed the NCLEX-RN exam on the first attempt upon graduation from the BSN program. Of the 136 students that completed the BSN program and took the NCLEX-RN exam, 121 passed the NCLEX-RN and 15 failed the NCLEX-RN. The minimum ACT score was 17 and the maximum ACT score achieved was 30 among the graduate students who took the NCLEX-RN exam. This study's findings show an ACT score of 24 or higher revealed a 98\% pass rate on the NCLEX-RN. An ACT score of 21-23 revealed an 85\% pass rate, whereas an ACT score of 20 or below revealed a high risk for failing the NCLEX-RN exam, with $42 \%$ of the 12 students failing the exam. These findings support existing research on ACT admission tests as predictors of performance on the NCLEX-RN licensure exam [5] [26] [31].

The research results showed the correlation was shown to be significant $(p<0.05)$ between the BSC227 (anatomy) grades and passing the NCLEX-RN exam on the first attempt upon graduation from the BSN program. The anatomy course is a prerequisite course required to be completed with a $\mathrm{C}$ grade or higher in order to be admitted to the BSN program. Of the 48 students with A grade in the anatomy course, 44 (92\%) passed the NCLEX-RN. The results of this study support other research findings that focused on prerequisite science course grades as predictors of program completion and passing NCLEX-RN [5] [27] [32] [33]].

However, this study revealed that there is not a significant relationship $(p<0.05)$ in the correlation between the BSC228 (physiology) grades and passing the NCLEX-RN exam on the first attempt upon graduation from the BSN program. The physiology course is a prerequisite course required to be completed with a $\mathrm{C}$ grade or higher in order to be admitted to the BSN program.

\subsection{Secondary Research Question 1}

The preprogram admission criteria that best predicted completion of the nursing program and passing the NCLEX-RN exam was the ACT scores and the preprogram GPA. The correlation is significant $(p=0.01)$, which shows both ACT and the preprogram GPA are significant predictors of completing the BSN program and passing the NCLEX-RN exam on the first attempt. 


\subsection{Research Question 2}

Does the HESI Exit Exam score predict success on the NCLEX-RN exam? A total of 136 students completed the HESI Exit Exam and took the NCLEX-RN exam upon graduation. This study's results showed that the correlation is significant if the $p=$ or $<0.05$. The level of significance is 0.01 , which is significant; therefore the HESI Exit Exam score predicts success on the NCLEX-RN exam. Of the 136 students that took the HESI Exit Exam, 121 (89\%) passed the NCLEX-RN exam and 15 (11\%) failed the NCLEX-RN exam on the first attempt. The lowest score achieved on the HESI Exit Exam was 607, and the maximum score achieved was 1128.

The results of this study showed the HESI Exit Exam scores of 850 to 899 to be $94 \%$ accurate at predicting success on the NCLEX-RN exam, a score of 900 to 949 to be $91 \%$ accurate, and a score of 950 and above to be $100 \%$ accurate in predicting success. This study's findings are consistent with the results of a research study by Young and Langford [22], which reported that the common benchmark score of 850 on the HESI Exit Exam to be $97.5 \%$ accurate in predicting success, and a score of 900 or above to be $98.3 \%$ accurate in predicting success on the first attempt at taking the NCLEX-RN exam. This study showed the pass rate decreased significantly with scores less than 850 , with a score of 750 - 799 to be $70 \%$ accurate in predicting success, and a score of 650 to 699 was shown to be a $25 \%$ accurate in predicting success. The findings revealed that $100 \%$ of the students with scores below 649 failed the NCLEX-RN exam on the first attempt.

This study's findings correlate with recent studies that reported a correlation between HESI scores and student success [14] [21] [22] [34] [35]. However, Spurlock and Hunt [36] concluded that the HESI Exit Exam could not accurately predict failure on the NCLEX-RN exam and that schools should not use a required HESI Exit Exam score as a nursing school curriculum requirement in order to graduate and take the licensure exam. The HESI Exit Exam scores should be used as a predictor of success and used to identify these at-risk students so that remediation or interventions can be implemented to help ensure success in completing the program and passing the NCLEX-RN [34] [37]-[41].

\subsection{Secondary Research Question 2}

The HESI Exit Exam score range that best predicted the first time pass rate on the NCLEX-RN exam was scores 950 and above. Of the 56 students that achieved a score of 950 and above on the HESI Exit Exam, 100\% passed the NCLEX-RN exam on the first attempt. The pass rate decreases significantly with the scores less than 850, which is the score range with below average of passing the NCLEX-RN, and it is also the score range requiring remediation in this BSN program. The findings correlate with a study by De Lima et al. [34] that reported the HESI scores correlate with student success.

\section{Limitations}

Further studies need to be completed with other nursing schools, as this study is limited to a BSN program located in the eastern part of the United States. This BSN program lacks ethnic diversity, as it is made up of 96\% Caucasian students, so the results of this study may be difficult to generalize to other nursing school student populations with more diversity located throughout the United States [42] [43]. Studies of other nursing programs with more diversity within the nursing student population would provide more research data that may be applicable to other programs throughout the United States. The findings are reflective of the unique nursing student population at the college in this study, and the nursing student population may not be reflective of the population within the state or at other colleges.

\section{Conclusions}

There is little empirical data on retention in a BSN program, as well as passing the NCLEX-RN exam, based on data on student aptitude [9]. Using the Pearson R correlational test, this study identified a significant relationship $(p<0.01)$ between the preprogram GPA, ACT scores, anatomy grades, and the HESI Exit Exam scores with the completion of the BSN program and passing the NCLEX-RN. The results of this study revealed that the preprogram admission criteria that best predicted the completion of the BSN program and passing the NCLEX-RN on the first attempt were the ACT scores and the preprogram GPA.

Passing the first semester nursing courses has been shown to be a strong predictor of completing the program and passing the NCLEX-RN exam [9] [27]. The results of this study revealed that the largest attrition occurred 
in the first semester of the BSN program, which correlated with the results of four studies that reported the attrition rate was highest in the first semester of the program [9] [27] [44]-[46]. Seidman's theory [11] served well as a guide for this study in assessing the academic variables such as admission data and HESI Exit Exam scores as predictors of student retention and success in completing this BSN program and passing the NCLEX-RN licensure exam on the first attempt. Seidman's retention theory could be used in future studies when assessing variables in predicting student retention and identifying these at-risk students.

Educators may use the results of this study to help identify these at-risk students early on. Further studies on admission criteria and standardized testing would help nurse educators identify nursing applicants most likely to succeed in the program and passing the NCLEX-RN licensure exam, thus ensuring a competent nursing workforce and help to meet the nursing shortage in the future [47]-[50] By reviewing the variables of the nursing curriculum that can predict success on the NCLEX-RN, measures can be used to prevent nursing student attrition and promote completion of the nursing program and passing the NCLEX-RN for all students.

\section{References}

[1] American Association of Colleges of Nursing [AACN] (2014) Nursing Shortage Fact Sheets. http://www.aacn.nche.edu/media-relations/fact-sheets/nursing-shortage.htm

[2] Buerhaus, P.I., Staiger, D.O. and Auerbach, D.I. (2009) The Future of the Nursing Workforce in the United States: Data, Trends, and Implications. Jones and Bartlett Publishers, Sudbury.

[3] American Association of Colleges of Nursing [AACN] (2011) Nursing Shortage. http://www.aacn.nche.eduMediaFactSheet/NursingShortage.htm

[4] Bureau of Labor Statistics (2012) The 30 Occupations with the Largest Projected Employment Growth, $2010-2020$. http://www.bls.gov/news.release/ecopro.t06.htm

[5] Gilmore, M. and Lyons, E.M. (2012) NURSING 911: An Orientation Program to Improve Retention of Online RNBSN Students. Nursing Education Perspectives, 33, 45-47. http://dx.doi.org/10.5480/1536-5026-33.1.45

[6] McGregor, A. (2007) Academic Success, Clinical Failure: Struggling Practices of a Failing Student. Journal of Nursing Education, 46, 504-511.

[7] Porter, K.B. (2008) Current Trends in Student Retention: A Literature Review. Teaching and Learning in Nursing, 3, 3-5. http://dx.doi.org/10.1016/j.teln.2007.09.001

[8] Brown, J. and Marshall, B.L. (2008) A Historically Black University’s Baccalaureate Universities Enrollment and Success Tactics for Registered Nurses. Journal of Professional Nursing, 24, 21-29. http://dx.doi.org/10.1016/j.profnurs.2007.06.006

[9] Newton, S.E. and Moore, G. (2009) Use of Aptitude to Understand Bachelor of Science in Nursing Student Attrition and Readiness for the National Council Licensure Examination-Registered Nurse. Journal of Professional Nursing, 25, 273-278. http://dx.doi.org/10.1016/j.profnurs.2009.01.016

[10] Silvestri, L.A., Clark, M.C. and Moonie, S.A. (2013) Using Logistic Regression to Investigate Self-Efficacy and the Predictors for National Council Licensure Examination Success for Baccalaureate Nursing Students. Journal of Nursing Education and Practice, 3, 21-34. http://dx.doi.org/10.5430/jnep.v3n6p21

[11] Seidman, A.(2005) College Student Retention: Formula for Student Success. American Council on Education/Praeger, Westport.

[12] American Nursing Association (2014) Demographics. http://www.nursingworld.org

[13] American Association of Retired Persons (2009) How Can I Find Info in Age-Line on Specific Age Groups. www.aacc.nche.edu/newsevents/news/articles/pages/102020091.aspx

[14] Adamson, C. and Young, A. (2012) Predicting NCLEX Success with the HESI Exit Exam: Fourth Annual Validity Study. Trauma, 20, 261-267.

[15] Murray, K.T., Merriman, C.S. and Adamson, C. (2008) Use of the HESI Admission Assessment to Predict Student Success. Computers, Informatics, Nursing, 26, 61-66. http://dx.doi.org/10.1097/01.NCN.0000304781.27070.a7

[16] Giddens, J. (2009) Changing Paradigms and Assumptions: Redefining Quality and NCLEX-RN Pass Rates. Journal of Nursing Education, 48, 123-124. http://dx.doi.org/10.3928/01484834-20090301-04

[17] Jeffreys, M.R. (2012) Nursing Student Retention: Understanding the Process and Making a Difference. 2nd Edition, Springer Publishing Company, New York, 55-309.

[18] Auerbach, D.I., Buerhaus, P.I. and Staiger, D.O. (2007) Better Late than Never: Workforce Supply Implications of Later Entry into Nursing. Health Affairs, 26, 178-185. http://www.healthaffairs.org/ 
http://dx.doi.org/10.1377/hlthaff.26.1.178

[19] Allan, J.D. and Aldebron, J. (2008) A Systematic Assessment of Strategies to Address the Nursing Faculty Shortage, US. Nursing Outlook, 56, 286-297. http://dx.doi.org/10.1016/j.outlook.2008.09.006

[20] Roehrs, C.J. (2011) Getting Started: Needs and Preferences of Colorado Faculty for Graduate Education in Nursing. Nursing Education Perspectives, 32, 84-88. http://dx.doi.org/10.5480/1536-5026-32.2.84

[21] Lavandera, R., Whalen, D.M., Perkel, L.K., Hackett, V., Molnar, D., Steffey, C., Hershorin, I.R., Rafalko, S., Little, D. J. and Harris, J. (2011) Value-Added of HESI Exam as a Predictor of Timely First-Time RN Licensure. International Journal of Nursing Education Scholarship, 8, 1-2. http://dx.doi.org/10.2202/1548-923X.2152

[22] Young, A. and Langford, R. (2011) The Eighth E ${ }^{2}$ Validity Study for RNs Accuracy, Benchmarking, Remediation and Testing Practices. Elsevier, 1-4.

[23] Lodico, M., Spaulding, D. and Voegtle, K. (2010) Methods in Educational Research: From Theory to Practice. John Wiley \& Sons, San Francisco.

[24] MacWilliams, B., Schmidt, B. and Bleich, M. (2013) Men in Nursing. The American Journal of Nursing, 113, 38-44. http://dx.doi.org/10.1097/01.NAJ.0000425746.83731.16

[25] National League for Nursing, NLN (2011) Disposition of Applications to Basic RN Programs, 2009-10. http://www.nln.org/researchgrants/slides/pdf/AS0910 F04.pdf

[26] Grossbach, A. and Kuncel, N.R. (2011) The Predictive Validity of Nursing Admission Measures for Performance on the National Council Licensure Examination: A Meta-Analysis. Journal of Professional Nursing, 27, 124-128. http://dx.doi.org/10.1016/j.profnurs.2010.09.010

[27] Landry, L.G., Davis, H., Alameida, M.D., Prive, A. and Renwanz-Boyle, A. (2010) Predictors of NCLEX-RN Success across 3 Prelicensure Program Types. Nurse Educator, 35, 259-263. http://dx.doi.org/10.1097/NNE.0b013e3181f7f1c9

[28] Newton, S.E., Smith, L.H., Moore, G. and Magnan, M. (2007) Predicting Early Academic Achievement in a Baccalaureate Nursing Program. Journal of Professional Nursing, 23, 144-149. http://dx.doi.org/10.1016/j.profnurs.2006.07.001

[29] Shirrell, D. (2008) Critical Thinking as a Predictor of Success in an Associate Degree Nursing Program. Teaching and Learning in Nursing, 3, 131-136. http://dx.doi.org/10.1016/j.teln.2008.05.001

[30] Uyehara, J., Magnussen, L., Itano, J. and Zhang, S. (2007) Facilitating Program and NCLEX-RN Success in a Generic BSN Program. Nursing Forum, 42, 31-38. http://dx.doi.org/10.1111/j.1744-6198.2007.00063.x

[31] Higgins, B. (2005) Strategies for Lowering Attrition Rates and Raising NCLEX-RN Pass Rates. Journal of Nursing Education, 44, 541-547.

[32] McGahee, T.W., Gramling, L. and Reid, T.F. (2010) NCLEX-RN Success: Are There Predictors. Southern Online Journal of Nursing Research, 10, 1-14.

[33] McGann, E. and Thompson, J.M. (2008) Factors Related to Academic Success in At-Risk Senior Nursing Students. International Journal of Nursing Education Scholarship, 5, 1-15. http://www.bepress.com/ijnes/vol5/iss1/art19 http://dx.doi.org/10.2202/1548-923X.1465

[34] De Lima, M., London, L. and Manieri, E. (2011) Looking at the Past to Change the Future: A Retrospective Study of Associate Degree in Nursing Graduates' National Council Licensure Examination Scores. Teaching and Learning in Nursing, 6, 119-123. http://dx.doi.org/10.1016/j.teln.2011.01.001

[35] Young, A. and Wilson, P. (2012) Predicting NCLEX-RN Success: The Seventh Validity Study HESI Exit Exam. CIN: Computers, Informatics, Nursing, 30, 55-60.

[36] Spurlock, D.R. and Hunt, L.A. (2008) A Study of the Usefulness of the HESI Exit Exam in Predicting NCLEX-RN Failure. Journal of Nursing Education, 47, 157-166. http://dx.doi.org/10.3928/01484834-20080401-07

[37] Baker, S. (2010) Nurse Educator Orientation: Professional Development That Promotes Retention. Journal of Continuing Education in Nursing, 41, 413-417. http://dx.doi.org/10.3928/00220124-20100503-02

[38] Greenspan, V., Springer, P. and Ray, K. (2009) A Tri-Nodal Model for NCLEX-RN Success. Nurse Educator, 34, 101102. http://dx.doi.org/10.1097/NNE.0b013e3181a02722

[39] Harding, M. (2010) Usefulness of a Midcurricular Examination for Identifying At-Risk Nursing Students. Computers, Informatics, Nursing, 28, 178-182. http://dx.doi.org/10.1097/NCN.0b013e3181d783e5

[40] Nibert, A., Young, A. and Adamson, C. (2008) Predicting NCLEX Success with the HESI Exit Exam: Fourth Annual Validity Study. Nurse Educator, 9, 28-34. http://dx.doi.org/10.1097/01.NCN.0000336439.16918.8b

[41] Roa, M., Shipman, D., Hooten, J. and Carter, M. (2011) The Costs of NCLEX-RN Failure. Nurse Education Today, 31, 373-377. http://dx.doi.org/10.1016/j.nedt.2010.07.009

[42] Creswell, J.W. (2008) Educational Research: Planning, Conducting, and Evaluating Quantitative and Qualitative Re- 
search. 3rd Edition, Pearson Education, Upper Saddle River, 511-550.

[43] Creswell, J.W. (2013) Research Design: Qualitative, Quantitative, and Mixed Methods Approaches. 4th Edition, SAGE Publications, Thousand Oaks, 155-183.

[44] Jeffreys, M.R. (2007) Tracking Students through Program Entry, Progression, Graduation, and Licensure: Assessing Undergraduate Nursing Student Retention and Success. Nurse Education Today, 27, 406-419. http://dx.doi.org/10.1016/j.nedt.2006.07.003

[45] Peterson, V. (2009) Predictors of Academic Success in First Semester Baccalaureate Nursing Students. Social Behavior \& Personality: An International Journal, 37, 411-417. http://dx.doi.org/10.2224/sbp.2009.37.3.411

[46] Kuh, G. (2008) Diagnosing Why Some Students Don’t Succeed. Chronicle of Higher Education, 55, 72-74.

[47] DiBartolo, M.C. and Seldomridge, L.A. (2008) A Review of Intervention Studies to Promote NCLEX-RN Success of Baccalaureate Students. Computers, Informatics, Nursing, 33, 785-835. http://dx.doi.org/10.1097/01.NCN.0000336449.70283.16

[48] Schmidt, B. and MacWilliams, B. (2011) Admission Criteria for Undergraduate Nursing Programs. Nurse Educator, 36, 171-174. http://dx.doi.org/10.1097/NNE.0b013e31821fdb9d

[49] Seldomridge, L.A. and DiBartolo, M.C. (2004) Can Success and Failure Be Predicted for Baccalaureate Graduates on the Computerized NCLEX-RN? Journal of Professional Nursing, 20, 361-368. http://dx.doi.org/10.1016/j.profnurs.2004.08.005

[50] Shelton, E.N. (2012) A Model of Nursing Student Retention. International Journal of Nursing Education Scholarship, 9, 1-16. http://dx.doi.org/10.1515/1548-923X.2334 